WENJIE HU ${ }^{1,2}$, S. MARKOVYCH ${ }^{1}$, KUN TAN ${ }^{1,4}$, O. SHORINOV ${ }^{1}$, TINGTING CAO ${ }^{2,3}$

\author{
${ }^{1}$ National aerospace university "Kharkiv Aviation Institute", Ukraine \\ ${ }^{2}$ School of Aeronautics and Astronautics, Nanchang Institute of Technology, China \\ ${ }^{3}$ School of Aircraft Engineering, Nanchang Hangkong University, Nanchang, China \\ ${ }^{4}$ China Scholarship Council
}

\title{
SURFACE REPAIR OF AIRCRAFT TITANIUM ALLOY PARTS BY COLD SPRAYING TECHNOLOGY
}

\begin{abstract}
Titanium alloys have the advantages of high specific strength, good corrosion resistance, high heat resistance, and low density, which is the main structural material of aerospace system components, including compressor blade, cartridge receiver, blisk, engine nacelle, thermal baffle and so on. At present, about three-quarters of titanium and titanium alloys in the world are used in the aerospace industry, including A350 for 14\%, F18 for $15 \%$, B787 for $15 \%$, SU-57 for $18 \%$, J-20 for $20 \%$, FC-31 fighters for $25 \%$, F35 for about $27 \%$, and F22 up to $41 \%$, etc, so it has the reputation of "space metal". However, its low wear resistance limits the further development of titanium alloy. Besides, its high manufacturing cost, if only require the occasion of surface performance can reduce the use of the substrate, and then reduced the cost. Therefore, the study of aircraft titanium alloy is of great significance, the protection of titanium alloy includes alloying technology and coating technology. Alloying technology mainly adds other elements on its basis to improve the performance, while the most popular method is coating technology, the present, there are many coating technologies, include highvelocity oxy-fuel (HVOF), HVAF, cold spraying, laser cladding, laser micro-fusion in-situ synthesized technology, micro-arc oxidation, laser melt injection (LMI), supersonic laser deposition (SLD) and supersonic plasma spray technology, surface repair titanium alloy parts by cold spraying technology are good ways to solve those problems. Because of its low process temperature, no oxidation, only plastic deformation, and repair efficiency are high, the protective coating has high bonding strength and good impact toughness. In this paper, the types and applications of aircraft titanium alloys were reviewed, the latest research results of surface repair of titanium alloys parts by cold spraying technology were reviewed, technological parameters of the cold gas dynamic spraying technology was analyzed, including powder size of particles, morphologies, critical velocity, particle compression rate, substrate preheating effects on the particle/substrate adhesion, etc.
\end{abstract}

Keywords: Titanium alloys; surface repair; cold spraying; protective coating; technological parameters.

\section{Aircraft Titanium Alloys}

\subsection{Introduction}

Titanium alloys have the advantages of low density, high specific strength and excellent corrosion resistance. So it is widely used in the field of aerospace. Ti alloys is the main structural material of aircraft parts, including compressor blade, cartridge receiver, blisk, engine nacelle, thermal baffle and so on. For instant, the titanium alloy used in the F35 for about $27 \%$, FC-31 fighters for $25 \%$. America's fourth-generation fighter jet, F22 engine, uses $41 \%$ [1] (table 1), it is the highest amount of titanium in use. Therefore, titanium alloy has the reputation of "space metal" [2].

There are three types of titanium alloys (table 2): $\alpha, \beta$ and $(\alpha+\beta)$ titanium alloys are widely used in aeroengines [3].

However, Titanium is easy to reactive at high temperature, great difficulty in smelting and high manufacturing cost, so it is an effective way to reduce the cost to study the repair of aircraft titanium alloys by coating technology. This paper takes aircraft Ti-6Al-4V alloy as an example, show its feasible to repair titanium alloy by cold spraying. Through the repair technology of cold spray, which brings great economic benefits. A significant cost to the department of defense of the United States supply-chain will be mitigated by Cold Spray technology [4].

Table 1

Mass fraction of titanium alloy used in different planes

\begin{tabular}{|l|c|c|c|}
\hline \multicolumn{1}{|c|}{ State } & $\begin{array}{c}\text { Aircraft } \\
\text { type }\end{array}$ & Service time & $\begin{array}{c}\text { Mass } \\
\text { fraction / \% }\end{array}$ \\
\hline USA & F/A 18E/F & 2002 & 15 \\
\hline USA & F/A 22 & 2005 & 41 \\
\hline USA & B787 & 2011 & 15 \\
\hline Europe & A350 & 2013 & 14 \\
\hline China & FC-31 & 2016 & 25 \\
\hline China & J-20 & 2017 & 20 \\
\hline USA & F35A & 2018 & 27 \\
\hline Russian & SU-57 & 2019 & 18 \\
\hline
\end{tabular}


Table 2

Titanium alloys use in aircraft [3]

\begin{tabular}{|c|c|}
\hline Alloy type & Chemical composition \\
\hline \multirow{9}{*}{$\begin{array}{l}\alpha(\text { near } \alpha) \\
\text { titanium alloy }\end{array}$} & Pure titanium \\
\hline & Ti-3Al-2.5V \\
\hline & Ti-5Al-2.5Sn \\
\hline & Ti-8Al-1Mo-1V \\
\hline & Ti-6Al-2Sn-4Zr-2Mo-Si(O.1-0.25) \\
\hline & $\begin{array}{c}\text { Ti-5.5Al-3.5Sn-3Zr- INb-0.25Mo- } \\
\text { 0.3Si(IMI829) }\end{array}$ \\
\hline & $\begin{array}{c}\text { Ti-5.5Al-4Sn-4Zr-0.3Mo-INb- } \\
\text { 0.5Si-0.006C(IMI834) }\end{array}$ \\
\hline & $\begin{array}{c}\text { Ti-5.8Al-4Sn-3.5Zr-0.7Nb-0.5Mo- } \\
\text { O.35Si-0.06C } \\
\text { (IMI } 884 \text { ) }\end{array}$ \\
\hline & $\begin{array}{c}\text { Ti-6Al-2.75Sn-4Zr 4Mo-0.45Si(Ti- } \\
1100)\end{array}$ \\
\hline \multirow{5}{*}{$\begin{array}{l}\beta \text { titanium } \\
\text { alloy }\end{array}$} & $\begin{array}{c}\text { Ti-6Al-2.75Sn-4Zr 4Mo- } \\
0.45 \mathrm{Si}(\mathrm{Ti}-1100)\end{array}$ \\
\hline & Ti-6Al-6V-2Sn \\
\hline & Ti-6Al-2Sn-2Cr-2Mo-2Cr-Si \\
\hline & Ti-6A1-2Sn-2Zr-6Mo \\
\hline & Ti-5Al-2Sn-2Zr-4Mo-4Cr(TC17) \\
\hline \multirow{5}{*}{$\begin{array}{l}(\alpha+\beta) \text { titani- } \\
\text { um alloy }\end{array}$} & Ti-13V-11Cr-3Al \\
\hline & Ti-10V-2Fe-3Al \\
\hline & Ti-15V-3Cr-3AI-3Sn \\
\hline & $\begin{array}{l}\text { Ti-15Mo-2.7Nb -3A-0.2Sn } \\
\text { (Timetal21S ) }\end{array}$ \\
\hline & Ti- 3AI-8V-6Cr-4Mo-4Zr(B-C) \\
\hline
\end{tabular}

\subsection{Current Coating Technology for Titanium Alloys}

The defects of titanium alloy include corrosion, abrasion and oxidation at high temperature, and so on. for example, Ti-5Al-2Sn-2Zr-4Mo-4Cr presents pitting corrosion in the environment of nitric acid and ravinelike corrosion pit in the environment of hydrochloric acid [5], especially in warships, where the corrosion problem is particularly serious.

Various protective coating technologies for titanium alloys have emerged. The repair methods of titanium alloy include HVOF [6], HVAF [6], cold spraying [7], laser cladding [8], laser micro-fusion in-situ synthesized technology [9], micro-arc oxidation [10, 11], laser melt injection (LMI) [12], chromium-free dacro technology [13], supersonic laser deposition [14] (SLD), which is a newly developed material deposition tech- nique that synchronously combines the laser heating with cold spray (CS). And supersonic plasma spray technology [15], which are different from low plasma spray (LPPS).

For Ti-matrix coating, $\mathrm{Hu}$ [16] research on the wear and corrosion behavior of Ti-matrix functional gradient layer, indicated friction coefficient and wear rate decreased significantly, the value was $0.3 \ldots 0.5$ times of Ti600 substrate. Zhou Heng research on $\mathrm{NiCrAl}+\mathrm{YSZ}+\mathrm{NiCrAl} /$ Bentonite composite coatings with thickness of $2 \mathrm{~mm}$ were prepared by plasma spraying and flame spraying [17] on the surface of Ti40 alloy, Zhang [18] study the effect of TiN/Ti coating structure on equivalent plastic strain of Ti-6Al-4V titanium alloy after impact by ABAQUS, optimize the architecture parameter of TiN/Ti anti-erosion coating. Due to wear resistance of titanium alloy is poor, Cai [19] research on the micro-cracks in fretting wear of Ti-6Al-4V titanium alloy, showed that the increase of load and displacement reduced the binding effect during fretting wear.

In summary, 1) aircraft titanium alloy mainly includes three basic alloys: $\alpha, \beta,(\alpha+\beta)$, among which the $\alpha$ titanium alloys include Ti-3Al-2.5V, Ti-5Al-2.5Sn, Ti-8Al-1Mo-1V, etc., it mainly contains elements such as $\mathrm{Al}$, which can increase the tensile strength and creep stress of the alloy, reduce the density of titanium alloy and improve the specific strength; $\beta$ titanium alloy include Ti-6Al-2.75Sn-4Zr 4Mo-0.45Si, Ti-6Al-6V-2Sn, Ti-6Al-2Sn-2Cr-2Mo-2Cr-Si, etc., it has a high enough stable element content to be the preferred structural material for airframes and wings; $(\alpha+\beta)$ titanium alloy include Ti-13V-11Cr-3Al, Ti-10V-2Fe-3Al, Ti-15V3Cr-3AI-3Sn, etc., its maximum operating temperature is no more than $500^{\circ} \mathrm{C}$, and its welding performance and heat resistance are lower than $\alpha$ titanium alloy; 2) surface coating technology for repair of titanium alloys is an effective method, while the basic coating technology includes thermal spraying technology, such as HVOF (Porosity: 1.6...2\%), cold spraying technology (Porosity $<0.5 \%$ ), Plasma spraying technology (Porosity: $5 \%$ ), Arc spray (Porosity: $10 \ldots 20 \%$ ), etc. Comparative analysis of porosity, cold spraying technology has obvious advantages over other technologies.

\section{Surface Repair of Aviation Titanium Alloys by Cold Spray}

Cold spraying technology for surface repair has great advantages: first of all, the parts do not need to preheat, and the heat in the repair process is small; Secondly, the repair efficiency is high (>95\%) and the speed is fast. The final coating has high bonding strength and good impact toughness. Unlike thermal spray, cold spray is capable of producing dense and thick coatings exhibiting extremely low porosity 
(<0.5\%), while avoiding oxidation, phase transformations and adverse residual stresses for a wide selection of metals, cermets, and other material mixtures. Cold spraying technology will become a hot trend in remanufacturing and repairing parts.

In view of the aircraft titanium alloy variety, In this paper, the feasibility of cold spraying repair technology was discussed with the classic aviation Ti-6Al$4 \mathrm{~V}$ titanium alloy.

\subsection{Cold Gas Dynamic Spray(CGDS)}

Cold Gas Dynamic Spray (CGDS) was first developed by Papyrin [20] et al. in the mid-1980s at the Institute of Theoretical an Applied Mechanics of the Russian Academy of Science in Novosibirsk while working with tracer particles in supersonic wind tunnels [21]. Major innovative development began in the 1950s by Rochevill, using a gas flow at a velocity higher than those obtained with the existing methods at that time. The flow of gas through a nozzle called the De Laval Nozzle produces a uniform thin coating [22 - 24]. The deposition during CGDS can be summarised into the molecular attraction between the surface deposit of the particles and the substrates and in-built deposit growth. At a supersonic velocity, particles impact and plastically deform on the substrate. The deformation process results in adhesion to the surface [25 - 30]. Compared with thermal spraying, since cold spraying is carried out at a lower temperature, the driving force for phase transformation is small, solid particles are not easy to oxidize, and the phenomenon of grain growth is not easy to occur. Because of the advantages of cold spraying [31], some researchers [32 - 39] begin to study it. Wong [40] indicate that high deposition efficiency, values as high as $100 \%$ for titanium and copper.

Powder (table 3) that can be used for cold spraying technology include pure metals such as $\mathrm{Al}, \mathrm{Zn}, \mathrm{Cu}, \mathrm{Ni}$, $\mathrm{Ti}, \mathrm{Ag}, \mathrm{Co}, \mathrm{Fe}, \mathrm{Nb}$, super alloy and high hardness ceramic of metallic coatings, ceramic coatings and organic coatings [41 - 43]. These coatings can not only be used to repair defective parts, but also can be made by rapid near-net molding. Based on the cold spray technology for aluminum and magnesium alloy repair has become mature [44 - 48], the application of aircraft as shown in the fig. 1, fig. 2 and fig. 3 .

\subsection{Repair Process of Ti Alloy parts with Cold Spray}

Cold spraying is a very good method to repair titanium alloy, which heat effect of the parts is small, compared with other thermal repair has a great advantage, especially for heat sensitive materials [49].

Jin Lei [50] utilize Ti-6Al-4V, Ti and $\mathrm{Al}_{2} \mathrm{O}_{3}$ mixed powder on the damaged surface of Ti-6Al-4V titanium alloy thin wall plate to get the repair coating by cold sprayed. The repair coating has good characteristics.

Table 3

Powders that can be used for cold spraying

\begin{tabular}{|c|c|}
\hline $\begin{array}{c}\text { Powder } \\
\text { types }\end{array}$ & \multicolumn{1}{c|}{$\begin{array}{c}\text { Powders Chemical } \\
\text { composition }\end{array}$} \\
\hline $\begin{array}{c}\text { Pure metal } \\
\text { coating }\end{array}$ & $\begin{array}{c}\text { Aluminum, Magnesium, Copper, } \\
\text { Titanium, Zinc, Nickel, silver, } \\
\text { tantalum, molybdenum, etc. }\end{array}$ \\
\hline $\begin{array}{c}\text { Nonmetal } \\
\text { coating }\end{array}$ & Ceramic, etc. \\
\hline Alloy coating & $\begin{array}{c}\text { Al alloy, Mg alloy, Cu alloy, Ti } \\
\text { alloy, Zn alloy, Ni alloy, Ag alloy, } \\
\text { etc. }\end{array}$ \\
\hline $\begin{array}{c}\text { Al-Zn, W-Cu, Al-Ti, Al-Ni, Al-Cu, } \\
\text { Al-Fe, Al-SiC, Al-TiN, Al-Al2O3, } \\
\text { Al-Mg17Al12, Al-FeSiBNbCu, } \\
\text { WC-Co, Cr3C2-NiCr, etc. }\end{array}$ \\
\hline
\end{tabular}

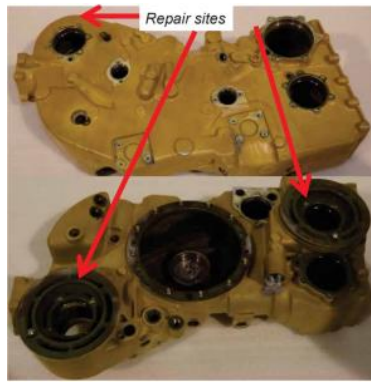

Fig. 1. AMAD Housing

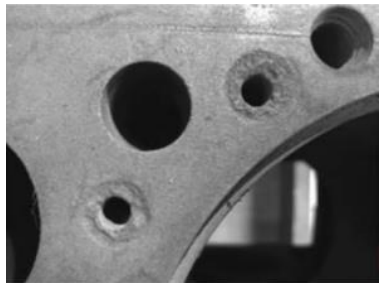

(a)

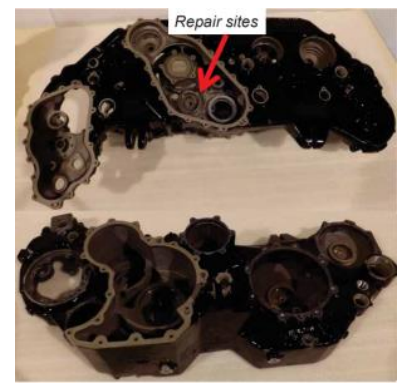

Fig. 2. ADG Housing

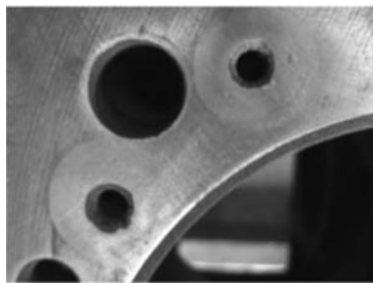

(b)
Fig. 3. Cold spray repair steyr engine channel corrosion area [53]:

$a$ - before the repair; $b$ - after the repair

Ogawa [51] used $\mathrm{Al}$ and its alloy coating to repair parts in the space shuttle solid-fuel rocket boosters and aircraft structures. The United States army research laboratory [52] also used cold spraying technology to repair the magnesium alloy crankcase shell of the helicopter.

Jean-Louis [54] Pelletier provided simulation about Ti-6Al-4V coating onto Ti-6Al-4V substrate using low pressure cold spray, simulated damage repair was successfully, and the coating quality is no major effect. This phenomenon associated to the high-velocity of the particles hitting the substrate and non-recovery of 
the dislocations. Such strain hardening increases with the degree of particle deformation. So Ti-6Al-4V alloy parts could be repaired efficiently by producing Ti-6Al-4V coating on a machined flat surface or with a 10 to 1 slope ( 6 degrees) or less. As fig. 4 and fig. 5 show, the interface between the coating and the substrate is very tight. The black dark area are the coating porosities [55], porosity is found to be $2.69 \pm 0.28 \%$.

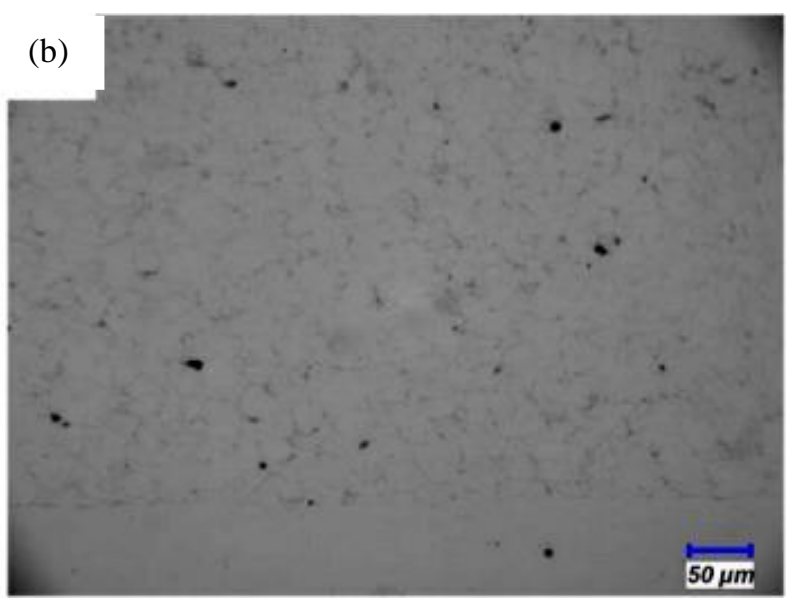

Fig. 4. Example of Simulated damage repair of Ti-6Al-4V with repair microstructure under optical microscope [54]

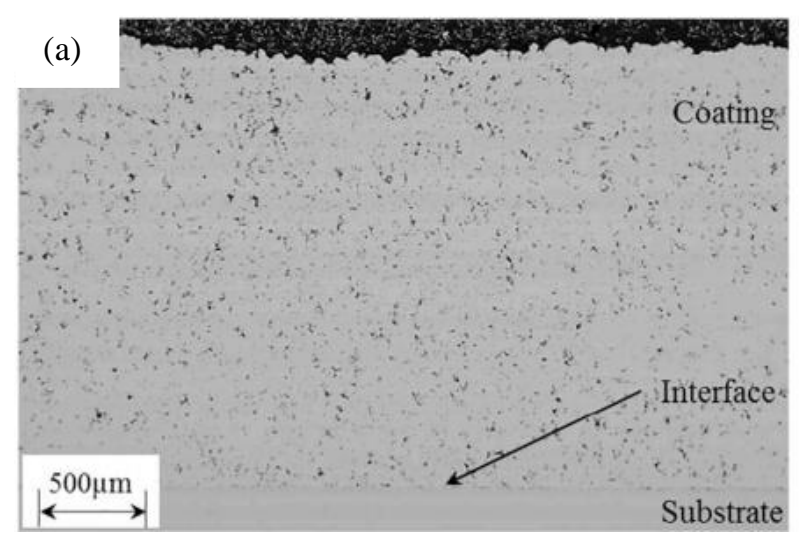

Fig. 5. Cold spray deposit, substrate and the interface, the dark ares in the coating porosities [55]

Cao Congcong [56] research on Ti-6Al-4V (fig. 6) coating were deposited by cold spray on surfaces of Ti-6Al-4V substrates, show higher micro-hardness, better bending property, smooth fractured surface characterized by brittle fracture with no phase change happened, which confirmed the feasibility of repairing titanium alloy components by cold spray technique.

Ti-6Al-4V particles deposited on Ti-6Al-4V substrate, mainly by mechanical combination, forming a dense coating (fig. 6, a). The interface between particles and particles in coating is closely bonded, and mainly combined by metallurgy, with some small pores (fig. 6, b)

As fig. 7 show, utilized the Lagrange finite element method to observe the obvious mechanical locking at the contact [57] surface between titanium particles and aluminum matrix (fig. 7). This shows that aluminum and titanium materials have good bonding characteristics by cold spraying technology.

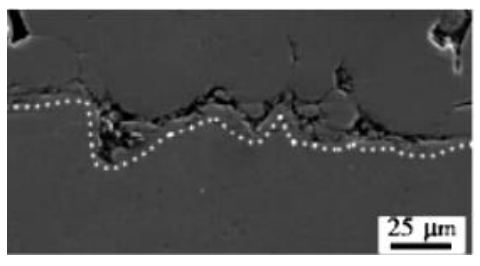

(a)

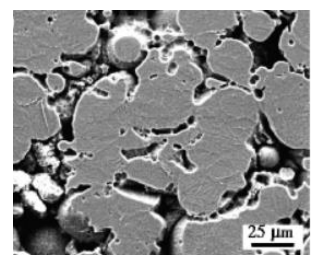

(b)
Fig. 6. Ti-6Al-4V/Ti-6Al-4V coating [56]: $\mathrm{a}$ - coating cross-section, $\mathrm{b}-$ the microstructure

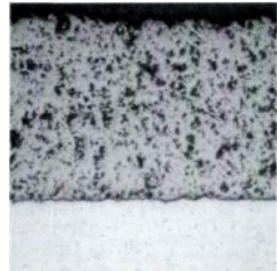

(a)

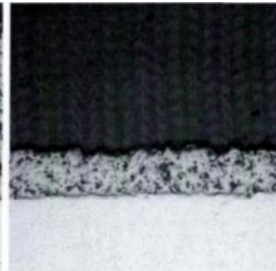

(b)

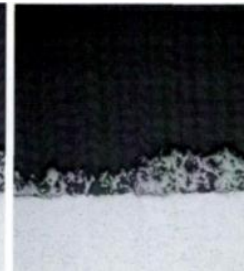

(c)
Fig. 7. cross-sectional OM micrographs of the cold sprayed titanium coating depositing aluminum substrate at different spray angles [57]:

$$
\mathrm{a}-90^{\circ} ; \mathrm{b}-75^{\circ} ; \mathrm{c}-60^{\circ}
$$

Base on the above analysis, it can be concluded that:

1) it has obvious advantages to repair the surface of Ti alloy parts by cold spraying technology;

2) on Ti-6Al-4V substrate, utilize Ti-6Al-4V as cold spraying coating, with an average porosity of $8 \%$ and a hardness of up to $300 \mathrm{MPa}$. Under the condition of nitrogen temperature of $600{ }^{\circ} \mathrm{C}$ and pressure of $3 \mathrm{MPa}, \mathrm{TC} 4$ coating with a porosity of $6.46 \%$;

3) repair surface of Ti-6Al-4V titanium alloy can choose Ti-6Al-4V, Ti and Al materials mixture, which are mechanically combined with good bonding performance. Repair coating material composition: Ti-6Al-4V is $40 \% \sim 70 \%, \mathrm{Ti}$ is $29 \% \sim 50 \%, \mathrm{Al}_{2} \mathrm{O}_{3}$ is $1 \% \sim 10 \%$, the matrix temperature of $\mathrm{Ti}-6 \mathrm{Al}-4 \mathrm{~V}$ titanium alloy is less than $150^{\circ} \mathrm{C}$, the pressure of $\mathrm{He}$ work gas is $0.6 \sim 1 \mathrm{MPa}$, spraying temperature is $300{ }^{\circ} \mathrm{C} \sim 600{ }^{\circ} \mathrm{C}$, spraying distance is $10 \sim 30 \mathrm{~mm}$. The porosity of repair coating is $0.1 \%$ and the hardness of repair coating reaches $1147 \mathrm{HV}_{0.3}$. 


\subsection{Cold Spraying Process Parameters of Titanium}

Cold spraying process has many parameters [58], including Powder size of particles, morphologies and property, Particle size should be in the appropriate range, if too small (fig. 8), the collision energy is insufficient to form effective deposition [59]; Particle velocity and critical velocity [60]; Substrate preheating effects on the particle/substrate adhesion, fig. 9 and fig. 10 shows, as the substrate temperature increases, decrease particle compression ratio and crater depth go up [61]; Substrate surface roughness effects on particle/substrate adhesion; Substrate surface texturing effects on the particle / substrate adhesion; Effects of nozzle unit design; Characteristic of propellant gas, for instant, Adding a small amount of helium to nitrogen can increase the exit velocity of gases and particles, while avoiding the high cost of using only helium to accelerate [62].

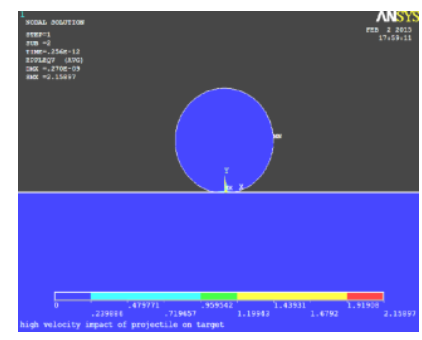

(a)

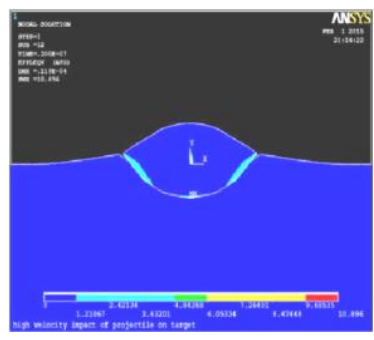

(b)
Fig. 8. Particle sizes and substrate of plastic strain [59]: $\mathrm{a}$ - size of $20 \mathrm{~nm} ; \mathrm{b}$ - size of $20 \mu \mathrm{m}$

The most important Cold spraying process parameters of titanium are critical velocity and temperature (table 4). critical velocity can be calculated by numerical simulation [63], Beyond the limit of critical velocity, a further increase in particle velocity results in a decrease in deposit porosity.

Han [64] research on morphology characteristics of Ti-6Al-4V particles colliding with the Ti-6Al-4V substrate at different temperature and velocity (fig. 11), showed that both thickness and density of the coatings prepared increase as gas pressure increases.

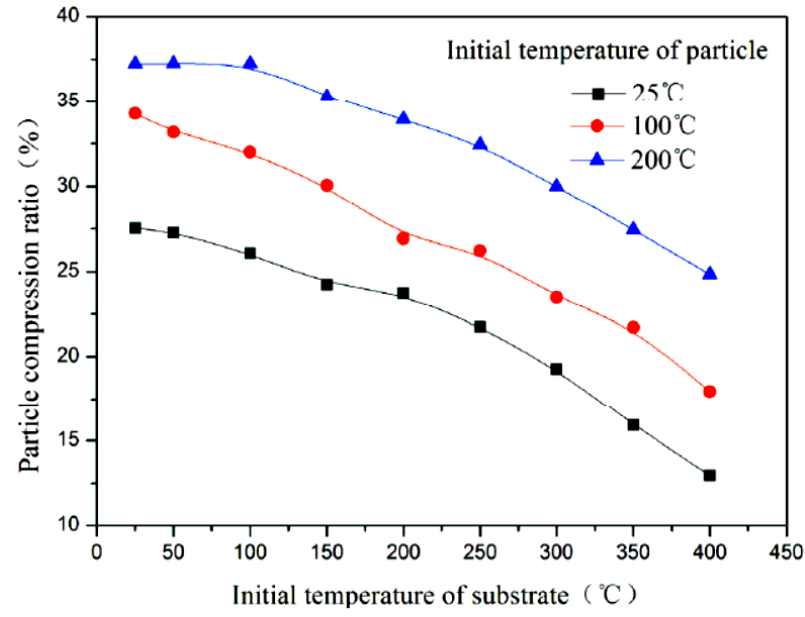

Fig. 9. Particle compression rate versus the initial temperature of substrate [61]

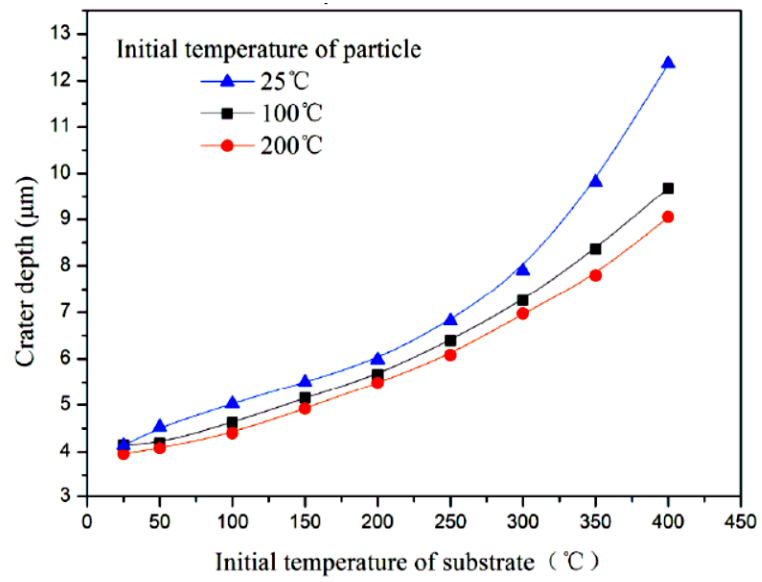

Fig. 10. Crater depth of substrate versus the initial temperature of substrate [61]

According to the analysis in fig. 11, particles of $700 \mathrm{~m} / \mathrm{s}$ and $800 \mathrm{~m} / \mathrm{s}$ have a very strong plastic deformation, and with the increase of particle velocity, the plastic deformation does not increase significantly, indicating that Ti-6Al-4V particles have effective deposition above $700 \mathrm{~m} / \mathrm{s}$.

Details of process parameters

\begin{tabular}{|c|c|c|c|c|c|c|c|c|}
\hline Partical & Substrate & $\begin{array}{c}\text { Propellant } \\
\text { gas }\end{array}$ & $\begin{array}{c}\text { Particle } \\
\text { diameter }\end{array}$ & $\begin{array}{c}\text { Tempera- } \\
\text { ture }\left({ }^{\circ} \mathrm{C}\right)\end{array}$ & $\begin{array}{c}\text { Pressure } \\
(\mathrm{Mpa})\end{array}$ & $\begin{array}{c}\text { Nozzle throat } \\
\text { diameter }(\mathrm{mm})\end{array}$ & $\begin{array}{c}\text { Nozzle } \\
\text { length }\end{array}$ & Ref. \\
\hline $\mathrm{Ti}$ & $\mathrm{Ti}$ & $\mathrm{N} 2$ & $29 \mu \mathrm{m}$ & $300-800$ & 3.4 & - & - & {$[69]$} \\
\hline $\mathrm{Ti}$ & $\mathrm{Ti}$ & $\mathrm{N} 2$ & $16-22 \mu \mathrm{m}$ & 600 & 2.4 & - & - & {$[70]$} \\
\hline $\mathrm{Ti}$ & $\mathrm{Ti}$ & $\mathrm{He}$ & $16 \mu \mathrm{m}$ & 600 & 1.5 & - & - & {$[71]$} \\
\hline $\mathrm{Ti}$ & $\mathrm{Ti6A} 14 \mathrm{~V}$ & $\mathrm{He}$ & $5-29 \mu \mathrm{m}$ & 260 & 1.6 & 3.8 & $90 \mathrm{~mm}$ & {$[71]$} \\
\hline
\end{tabular}




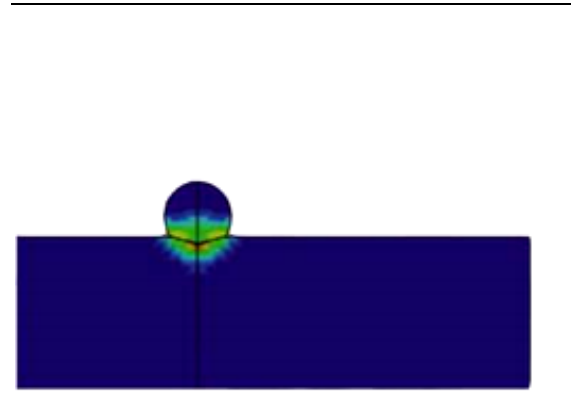

(a)

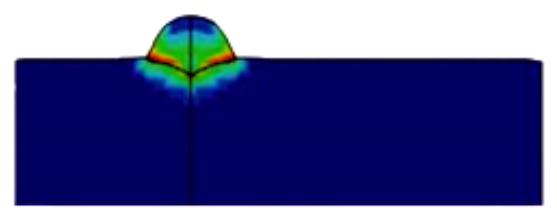

(b)

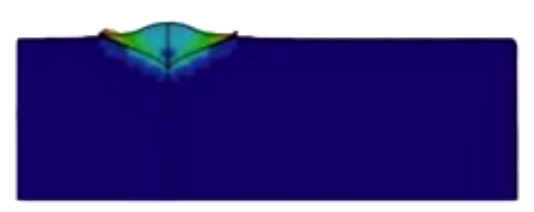

(c)

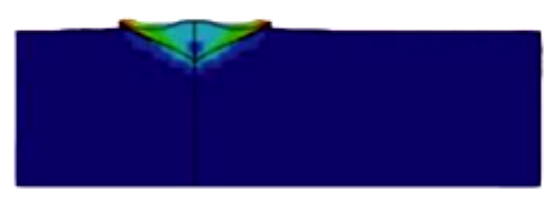

(d)

Fig. 11. Morphologies of the Ti-6Al-4V after colliding at different speeds [64]: $\mathrm{a}-500 \mathrm{~m} / \mathrm{s} ; \mathrm{b}-600 \mathrm{~m} / \mathrm{s} ; \mathrm{c}-700 \mathrm{~m} / \mathrm{s} ; \mathrm{d}-800 \mathrm{~m} / \mathrm{s}$

Yang [65] studied various concepts and calculation methods of critical velocity, For example, the recovery coefficient (fig. 12) determines the critical velocity.

Article [66] estimate the critical velocity by this method to be $690 \mathrm{~m} / \mathrm{s}$ for angular titanium powder. Schmidt [67] reported a critical velocity of around $750 \mathrm{~m} / \mathrm{s}$ for a $25 \mu \mathrm{m}$ titanium particle. Wong [68] meas- ured the critical velocity of spherical titanium powder between $505-610 \mathrm{~m} / \mathrm{s}$.
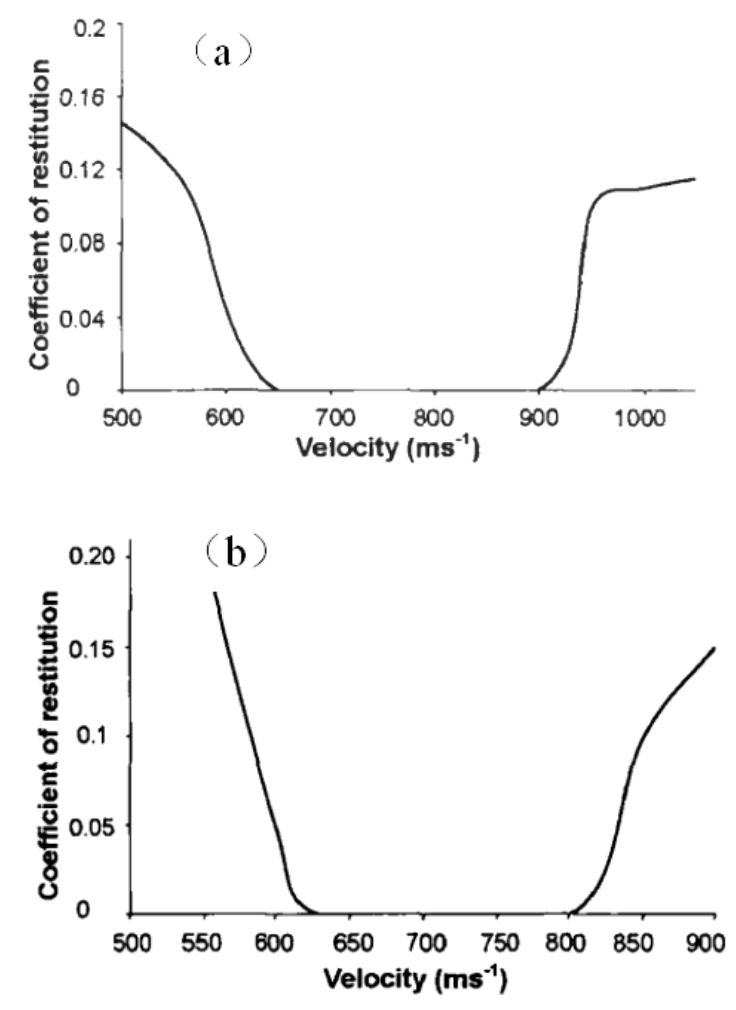

Fig. 12. The velocity range of coating formed by particle being bonded on substrate: $\mathrm{a}-\mathrm{Ti} / \mathrm{Ti} ; \mathrm{b}-\mathrm{Ti} / \mathrm{Al}[65]$

The temperature parameters of $\mathrm{Ti}$ and $\mathrm{Ti}-6 \mathrm{Al}-4 \mathrm{~V}$ are as follows table 4, for different conditions such as particle, substrate, particle diameter, propeller gas, pressure, nozzle throat diameter, etc., the suitable temperature is also different, which ranges from $260^{\circ} \mathrm{C}$ to $800{ }^{\circ} \mathrm{C}$.

\section{Conclusions}

Surface repair of aircraft titanium alloy parts by cold spraying technology has obvious advantages. The porosity of cold spray coating is generally less than $0.5 \%$.

1. Types of powder materials for aircraft titanium alloy include Ti-6Al-4V, Ti, $\mathrm{Al}, \mathrm{Al}_{2} \mathrm{O}_{3}$, steel, etc.

2. Cold spraying technology can be sprayed on almost any material, including $\mathrm{Al}, \mathrm{Zn}, \mathrm{Cu}, \mathrm{Ni}, \mathrm{Ti}, \mathrm{Ag}$, $\mathrm{Co}, \mathrm{Fe}, \mathrm{Nb}$, super alloy and high hardness ceramic of metallic coatings, ceramic coatings and organic coatings.

3. Hardness of Ti-6Al-4V substrate is high, and porosity of cold spraying coating is usually more than $1 \%$. If Ti-6Al-4V is used as spraying material, the porosity is only $6.46 \%$, but mixing Ti-6Al-4V (60\%), $\mathrm{Ti}(33 \%)$ and $\mathrm{Al}_{2} \mathrm{O}_{3}(7 \%)$, the porosity can reach $0.1 \%$ 
and the hardness of repair coating reaches $1147 \mathrm{HV}_{0.3}$, which solves the problem that the mechanical properties of coating are affected by the large porosity.

4. Development of special software and procedures for technological parameters optimization can provide serious reserve of implementation of different material mixtures as well as regulation of energy of cold spraying process for formation of special predicted physical-mechanical parameters of a coating-substrate complex. As the preheating of the matrix increases, the compression ratio of the particles decreases. Ti-6Al-4V alloy needs more than $700 \mathrm{~m} / \mathrm{s}$ to be effectively deposited. The critical velocity of titanium deposition on the titanium substrate and the aluminum substrate are $650 \mathrm{~m} / \mathrm{s} \sim 900 \mathrm{~m} / \mathrm{s}$ and $630 \mathrm{~m} / \mathrm{s} \sim 800 \mathrm{~m} / \mathrm{s}$.

\section{References (GOST 7.1:2006)}

1. Li, M. Y. Structure of titanium alloys materials for aviation [Text] / M. Y. Li // World Nonferrous Metals. -2006 . - No. 6. - P. 17-20.

2. Liu, B. TITANIUM 2008: the international titanium industry, preparation technology and application development [Text] / B. Liu, Y. B. Liu, X. Yang // Powder Metallurgy Materials Science and Engineering. 2009. - Vol. 2, No. 14. - P. 67-73.

3. Jin, H. X. Research development of titanium alloy in aerospace industry [Text] / H. X. Jin // The Chinese Journal of Nonferrous Metals. - 2015. - Vol. 2, No. 35. - P. 280-292.

4. Champagne, V. Cost and Performance Report: Cold Spray for Repair of Magnesium Components [Electronic resource] / V. Champagne // Department of Defense, Environmental Security Technology Certification Program. - November 2011. - Available at: https://apps.dtic.mil/dtic/tr/fulltext/u2/a572962.pdf. 12.12.2019

5. Wang, J. S. The corrosion behavior and its effect on fatigue life of TC17 Titanium alloy [Text] / J. S. Wang. - Xiamen university, 2017.

6. Zhao, Z. Discussion on preparation technology of titanium coating by thermal spraying [Text] /Z. Zhao // Welding. - 2011. - Vol. 6. - P. 16-21.

7. Sun, W. Adhesion, tribological and corrosion properties of cold-sprayed CoCrMo and Ti6Al4V coatings on 6061-T651 Al alloy [Text] / W. Sun, A. W. Y. Tan, I. Marinescu et al // Surface and Coatings Technology. - 2017. - No. 326. - P. 291-298.

8. Zhao, Z. Influence of $\alpha / \beta$ interface phase on the tensile properties of laser cladding deposited Ti-6Al-4V titanium alloy [Text] /Z. Zhao, J. Chen, S. Guo, et al // Journal of Materials Science \& Technology. - 2017. No. 33. - P. 675-681.

9. Liu, X. In-situ synthesized TiN coating by laser nitriding on TC4 surface [Text] / X. Liu, et al // Aviation manufacturing technology. -2018 . -Vol. 61, No. 23. P. 52-57.
10. Li, Y. M. Investigation on preparation and wear resistance of micro-arc oxidation composite ceramic coating on TC4 titanium alloy [Text] / Y. M. Li, et al // Function Materials. - 2015. - Vol. 46, No. 9. - P. 09128-09132.

11. Wu, Y. Research of composite coating on TC4 titanium alloy surface [Text] / Y. Wu. - Shenyang Ligong University, 2016.

12. Song, Y. Z. Microstructure analysis of laser melt injection WC/TC4 composite coating on titanium alloy surface for aircraft flaps [Text] / Y. Z. Song // Weld. - 2018. - No. 11. - P. 44-49.

13. Han, X. J. Research on preparation of $\mathrm{Zn}-\mathrm{Al}$ alloy coating on the surface of TC4 Alloy and its resistance to titanium/aluminum contact corrosion [Text] I X. J. Han. - Nanjing University of Aeronautics and Astronautics, 2016.

14. Li. B. Micro-structure and corrosion-resistant property of Ti6Al4V coating prepared by supersonic laser deposition [Text] / B. Li, L. J. Wu, et al. // China Surface Engineering. - 2018. - Vol. 5, No. 31. - P. 159166.

15. Liu, M. Property Investigation of Ti Coating Deposited by Supersonic Plasma Spray [Text] / M. Liu // Thermal Spray Technology. - 2016. - Vol. 1, No. 8. P. 5-10.

16. Hu, F. Y. The wear and corrosion behavior of Ti-matrix functional gradient layer [Text] / F. Y. Hu // Function Materials. - 2012. - Vol. 1, No. 43. - P. 36-38.

17. Zhou, H. Effect of Preparation of $\mathrm{NiCrAl}+\mathrm{YSZ}+\mathrm{NiCrAl} /$ Bentonite Flame-retardant Sealing Composite on Titanium Alloy [Text] / H. Zhou // Thermal spray Technology. - 2018. - Vol. 3, No. 10. P. 12-16.

18. Zhang. Y. F. Numerical simulation on the erosion behavior of aeroengine blade substrate with TiN/Ti coating [Text] / Y. F. Zhang, et al. // Surface Technology. - 2015. - Vol. 7, No. 44. - P. 81-85.

19. Cai, J. Q. Study on the micro-cracks in fretting wear of Ti-6Al-4V titanium alloy [Text] / J. Q. Cai. Lanzhou university of technology, 2017.

20. Papyrin, A. N. Cold spray technology 2007. Elsevier, 2017.

21. Zhao. G. F. Application of cold spraying equipment and cold spraying technology [Text] / G. F. Zhao, Y. Y. Wang et al // Surface technology. - 2017. Vol. 11, No. 46. - P. 198-205.

22. Irisson. E. Review on cold spraying processes and technology: Part 1 - Intellectual property [Text] / E. Irisson, J. G. Legoux, A. N. Ryabinin, B. Jodoin, C. Moreau // Therm. Spray Technol. - 2008. - No. 17. P. 495-516.

23. Raoelison. R. N. Cold gas dynamic spray technology: a comprehensive review of processing conditions for various technological developments till to date [Text] / R. N. Raoelison, Y. Xie et al. // Addit. Manuf. 2018. - No. 19. - P. 134-159.

24. Singh, $H$. Cold spraying technology: future of coating deposition processes [Text] / H. Singh, T. S. 
Sidhu // Frat. Ed. Integrita Strutt. - 2012. - No. 22. - P. 69-84.

25. Moridi, A. Cold spraying coating: review of material systems and future perspectives [Text] / A. Moridi, S. M. Hassani-Gangaraj, M. Guagliano, M. Dao // Surf. Eng. - 2014. - No. 30. - P. 369-395.

26. Marrocco, T. Production of titanium deposits by cold-gas dynamic spray: numerical modeling and experimental characterization [Text] / T. Marrocco, D. G. McCartney, P. H. Shipway, A. Sturgeon // Thermal Spray Technology. - 2006. - No. 15. - P. 263-272.

27. MacDonald, D. Cold spraying of armstrong process titanium powder for additive manufacturing [Text] / D, MacDonald, R. Fernandez, F. Delloro, B. Jodoin // Thermal Spray Technology. - 2017. - No. 26. - P. 598-609.

28. Steenkiste, T. H. V. Aluminum coatings via kinetic spray with relatively large powder particles [Text] /T. H. V. Steenkiste, J. R. Smith, R. E. TeetsSurf // Coatings Technol. - 2002. - No. 154. - P. 237-252.

29. Gruicjic, M. Analysis of the impact velocity of powder particles in the cold-gas dynamic-spraying processes [Text] / M. Gruicjic, C. L. Zhao, C. Tong // Mater. Sci. Eng. A. - 2004. - No. 368. - P. 222-230.

30. Assadi, H. Bonding mechanism in cold gas spraying [Text] / H. Assadi, F. Gartner, T. Stoltenhoff, H. Kreye // Acta Mater. - 2003. - No. 6454. - P. 43794394.

31. Karthikeyan, J. The Advantages and disadvantages of the cold spray coating process, in the cold spray materials deposition process: fundamentals and applications [Text] / J. Karthikeyan // V. K. Champagne Editor. - Woodhead; CRC Press, 2007. - P. 62-71.

32. Meyer, M. An analysis of the particulate flow in cold spray nozzles [Text] / M. Meyer // Mechanical sciences. - 2015. - Vol. 2, No. 6. - P. 127-136.

33. Silvello, A. Mechanical properties of cold sprayed Titanium and Nickel based coatings [Text] / A. Silvello // Surface Engineering. - 2015. - Vol. 1, No. 15. - P. 153-154.

34. Lu, B. Microstructure Analysis of Laser Remelting for Thermal Barrier Coatings on the Surface of Titanium Alloy - International symposium on materials applications and engineering [Text] / B. Lu, D. H. Wang, L. Xiao. - France : EDP Sciences, 2016.

35. Li, W. Y. Optimization of spray conditions in cold spraying based on the numerical analysis of particle velocity [Text] / W. Y. Li, C. J. Li // Trans. Nonferrous Met. Soc. China. - 2004. - Vol. 2, No. 14. - P. 4348

36. Cao. C. C., Li. W. Y. Simulation study on effect of cold spray nozzle material on particle / C. C. Cao, W. $Y$. , et al // Journal of netshape forming engineering, 2019. - Vol. 6, No. 11. - P. 149-153.

37. $\mathrm{Li}, \mathrm{C}$. J. Examination of the critical velocity for deposition of particles in cold spraying [Text] / C. J. Li, W. Y. Li // Journal of Thermal Spray Technology. 2006. - Vol. 2, No. 15. - P. 212-222.

38. Qing, Y. C. Morphological, structural and mechanical characterization of cold sprayed hydroxyap- atite coating [Text] / Y. C. Qing, Y. L. Zou // Surface and Coatings Technology. - 2019. - Vol. 1, No. 357. P. 910-923.

39. Effects of Gas Temperature, Gas Pressure and the Particle Characteristics on Cold Sprayed Pure Titanium Coating, in Thermal Spray 2009: Expanding Thermal Spray Performance to New Markets and Applications [Text] / B. R. Marple et al. - ASM International: Las Vegas, NV, 2009. - P. 231-236.

40. Wong, W. Influence of helium and nitrogen gases on the properties of cold gas dynamic sprayed pure titanium coatings, in Thermal spray: Global Solutions for Future Application [Text] / W. Wong, E. Irissou // B. R. Marple, et al., Editors. - ASM International: Singapore, 2010.

41. Kumar, S. Deposition characteristics of copper particles on Foughened substrates through kinetic spraying [Text] / S. Kumar, B. Gyuyeol, L. Changhee // Applied Surface Science. - 2009. - No. 255. - P. 34723479.

42. Yuan, X. G. Interfacial diffusion behavior of cold sprayed aluminum alloy on the surface of magnesium alloy [Text] / X. G. Yuan, et al // Journal of welding. - 2007. - Vol. 11, No. 28. - P. 9-11.

43. Zhang, H. B. Microstructure of cold spray $\mathrm{Ni}$ coating [Text] / H. B. Zhang, et al // Chinese journal of nonferrous metals. - 2008. - Vol. 8. - No. 18. - P. 1421-1425.

44. Yu, S. Q. Protection for cold sprayed coating on magnesium alloy [Text] / S. Q. Yu, et al // Surface technology. - 2018. - Vol. 5, No. 47. - P. 43-56.

45. Li, X. F. Application and prospect of cold spraying in welding engineering [Text] /X.F. Li, et al // Welding. - 2008. - No. 9. - P. 13-16.

46 Liu, Y. X. Cold spray process for magnesium alloy and properties of coating [Text] / Y. X. Liu. Shenyang university of technology, 2007.

47. Hu. J. W. Cold spray copper coating on aluminum alloy substrate [Text] / J. W. Hu, et al // Journal of Netshape Forming Engineering. - 2019. - Vol. 6, No. 11. - P. 154-160.

48. Yu, S. Q. Microstructure and corrosion behavior of cold sprayed aluminum alloy and aluminum matrix composite coating on magnesium alloy [Text] / S. Q. Yu et al // Aerospace shanghai. - 2018. - Vol. 4, No. 35. - P. 101-107.

49. Zhong, L. Research progress of precipitation mechanism and apparatus of cold spray [Text] / L. Zhong, Z. Y. Wang, H. D. Zhang // Surface technology. - 2015. - Vol. 4, No. 44. - P. 15-22.

50. Patent CN109207988A China, Cold spraying powder for surface damage repair of thin walled titanium alloy parts and a method for repair [Text] / Lei J. 2019.

51. Ogawa, K. Repairing of Degraded Hot Section Parts of Gas Turbines by Cold Spraying [Text] / K. Ogawa, T. Niki // Key Engineering Materials. - 2010. Vol. 417-418. - P. 545-548.

Doi: 10.4028/www.scientific.net/KEM.417-418.545. 
52. Champagne, $V . K$. The repair of magnesium rotorcraft components by cold spray [Text] / V. K. Champagne // Journal of failure analysis and prevention. - 2008. - Vol. 8, No. 2. - P. 164-175.

53. Li, W. Y. Application of cold spraying technology in additive manufacturing and repair in the manufacturing field [Text] / W. Y. Li, et al // Welding. - 2016. - Vol. 4. - P. 1-8.

54. Pelletier, J. L. Development of Ti-6Al-4V coating onto Ti-6Al-4V substrate using Low Pressure Cold Spray and Pulse Gas Dynamic Spray [Text] / J. L. Pelletier. - University of Ottawa, Ottawa, Canada. 2013.

55. Dibakor, B. Evaluation of residual stresses induced by cold spraying of Ti-6Al-4V on Ti-6Al-4V substrates [Text] / B. Dibakor, A. Bilal et al. // Surface \& Coating Technology. - 2019. - No. 374. - P. 591-602.

56. Cao, C. C. Influence of substrate hardness and thermal characteristics on microstructure and mechanical properties of cold sprayed TC4 titanium alloy coating [Text] / C. C. Cao // Materials Reports. - 2019. Vol. 1, No. 33. - P. 277-282.

57. Yin, S. A systematic investigation on the acceleration behavior and deposition mechanism of cold sprayed particles [Text] / S. Yin. - Dalian University of Technology, 2012.

58. Sunday, T. O. A comparative review on cold gas dynamic spraying processes and technologies [Text] /T. O. Sunday et al. - EDP Sciences, 2019.

59. Liu, C. G. The analysis on the particles acceleration performance and deposition mechanism in the cold-gas dynamic spraying processes [Text] / C. G. Liu. - University Of South China, 2015.

60. Li, T. F. Development on Cold Spray Apparatus [Text] / T. F. Li, et al. // Thermal Spray Technology. - 2011. - Vol. 3, No. 2. - P. 15-34.

61. Zhao, M. Effects of particle and substrate property on impact and adhesion process in clod spray by numerical simulation [Text] / M. Zhao. - Chongqing university, 2015.

62. $W u, X . K$. Numerical investigation on acceleration of gaseous mixture of nitrogen and helium on particles during cold spraying [Text] / X. K. Wu, X. L. Zhou et al // Materials engineering. - 2010. - Vol. 8. - P. 1215.

63. Meng, X. M. Numerical simulation of the effects of the impact velocity on the particle deposition characteristics in cold gas dynamic spraying [Text] / X. M. Meng, J. B. Zhang et al // Baosteel technology. 2011. - Vol. 5. - P. 17-22.

64. Han, L. Critical deposition velocity calculations and properties investigations of TC4 cold spray coatings [Text] / L. Han, et al // Surface Technology. 2017. - Vol. 46, No. 8. - P. 96-101.

65. Yang, Y. Research on Critical Velocity of Particle during Cold Spray Process [Text] / Y. Yang, et al. // Thermal spraying technology. - 2015. - Vol. 7, No. 4. - P. 1-16.

66. Marrocco, T. Production of titanium deposits by cold-gas dynamic spray: Numerical modeling and experimental characterization [Text] / T. Marrocco et al // Journal of Thermal Spray Technology. - 2006. - Vol. 2, No. 15. - P. 263-272.

67. Schmidt, T. Development of a generalized parameter window for cold spray deposition [Text] / T. Schmidt, F. Gartner // Acta Materialia. - 2006. - Vol. 3, No. 54. - P. 729-742.

68. Wong, W. Effects of Gas Temperature, Gas Pressure and the Particle Characteristics on Cold Sprayed Pure Titanium Coatings, in Thermal Spray 2009: Expanding Thermal Spray Perormance to New Markets and Applications [Text] / W. Wong, A. Rezaeian. - ASM International : Las Vegas, NV, 2009. - P. 231-236.

69. Wang, H. R. Corrosion behavior of cold sprayed titanium protective coating on 1 Crl3 substrate in seawater [Text] / H. R. Wang, W. Y. Li, L. Ma, J. Wang, Q. Wang // Surf. Coatings Technol. - 2007. - No. 201. - P. 5203-5206.

70. Zahiri, S. H. Elimination of porosity in directly fabricated titanium via cold gas dynamic spraying [Text] / S. H. Zahiri, C. I. Antonio, M. Jahedi // J. Mater. Process. Technol. - 2009. - No. 209. - P. 922- -929.

71. Cizek, J. Infuence of plasma and cold spraying deposited Ti Layers on high-cycle fatigue properties of Ti6Al4V substrates [Text] / J. Cizek, O. Kovarik, J. Siegl, K. A. Khor, I. Dlouhy // Surf. Coatings Technol. 2013. - No. 217. - P. 23-33.

\section{References (BSI)}

1. Li, M. Structure of titanium alloys materials for aviation. World Nonferrous Metals, 2006, no. 6, pp. 1720.

2. Liu, B., Liu, Y. B., Yang, X. et al. TITANIUM 2008: the international titanium industry, preparation technology and application development. Powder Metallurgy Materials Science and Engineering, 2009, vol. 2, no. 14 , pp. 67-73.

3. Jin, H. et al. Research development of titanium alloy in aerospace industry. The Chinese Journal of Nonferrous Metals, 2015, vol. 2, no. 35, pp. 280-292.

4. Champagne, V. Cost and Performance Report: Cold Spray for Repair of Magnesium Components. Department of Defense, Environmental Security Technology Certification Program, November 2011. Available at: https://apps.dtic.mil/dtic/tr/fulltext/u2/a572962.pdf (accessed 12.12.2019)

5. Wang, J. S. The corrosion behavior and its effect on fatigue life of TC17 Titanium alloy. Xiamen university, 2017.

6. Zhao, Z. Discussion on preparation technology of titanium coating by thermal spraying. Welding, 2011, vol. 6, pp. 16-21.

7. Sun, W., Tan, A. W. Y., Marinescu, I. et al. Adhesion, tribological and corrosion properties of coldsprayed CoCrMo and Ti6Al4V coatings on 6061-T651 Al alloy. Surface and Coatings Technology, 2017, no. 326, pp. 291-298. 
8. Zhao, Z., Chen, J., Guo, S. et al. Influence of $\alpha / \beta$ interface phase on the tensile properties of laser cladding deposited Ti-6Al-4V titanium alloy. Journal of Materials Science \& Technology, 2017, no. 33, pp. 675-681.

9. Liu, X. et al. In-situ synthesized TiN coating by laser nitriding on TC4 surface. Aviation manufacturing technology, 2018, vol. 61, no. 23, pp. 52-57.

10. Li, Y. M. et al. Investigation on preparation and wear resistance of micro-arc oxidation composite ceramic coating on TC4 titanium alloy. Function Materials, 2015, vol. 46, no. 9, pp. 09128-09132.

11. Wu, Y. Research of composite coating on TC4 titanium alloy surface. Shenyang Ligong University, 2016.

12. Song, Y. Z. et al. Microstructure analysis of laser melt injection WC/TC4 composite coating on titanium alloy surface for aircraft flaps. Weld, 2018, no. 11, pp. 44-49.

13. Han, X. J. Research on preparation of $\mathrm{Zn}-\mathrm{Al}$ alloy coating on the surface of TC4 Alloy and its resistance to titanium/aluminum contact corrosion. Nanjing University of Aeronautics and Astronautics, 2016.

14. Li, B., Wu, L. J. et al. Micro-structure and corrosion-resistant property of Ti6Al4V coating prepared by supersonic laser deposition. China Surface Engineering, 2018, vol. 5, no. 31, pp. 159-166.

15. Liu, M. Property Investigation of Ti Coating Deposited by Supersonic Plasma Spray. Thermal Spray Technology, 2016, vol. 1, no. 8, pp. 5-10.

16. Hu, F. Y. et al. The wear and corrosion behavior of Ti-matrix functional gradient layer. Function Materials, 2012, vol. 1, no. 43, pp. 36-38.

17. Zhou, $\mathrm{H}$. et al. Effect of Preparation of $\mathrm{NiCrAl}+\mathrm{YSZ}+\mathrm{NiCrAl} /$ Bentonite Flame-retardant sealing Composite on Titanium Alloy. Thermal spray Technology, 2018, vol. 3, no. 10, pp. 12-16.

18. Zhang, Y. F. et al. Numerical simulation on the erosion behavior of aeroengine blade substrate with TiN/Ti coating. Surface Technology, 2015, vol. 7, no. 44, pp. 81-85.

19. Cai, J. Q. Study on the micro-cracks in fretting wear of Ti-6Al-4V titanium alloy. Lan Zhou university of technology, 2017.

20. Papyrin, A. N. Cold spray technology 2007. Elsevier, 2017.

21. Zhao, G. F., Wang, Y. Y. et al. Application of cold spraying equipment and cold spraying technology. Surface technology, 2017, vol. 11, no. 46, pp. 198-205.

22. Irisson, E., Legoux, J.-G., Ryabinin, A. N., Jodoin, B., Moreau, C. Review on cold spraying processes and technology: Part 1 - Intellectual property. Therm. Spray Technol, 2008, no. 17, pp. 495-516.

23. Raoelison, R. N., Xie, Y. et al. Cold gas dynamic spray technology:a comprehensive review of processing conditions for various technological developments till to date. Addit. Manuf., 2018, no. 19, pp. 134 159.
24. Singh, H., Sidhu, T. S. et al. Cold spraying technology: future of coating deposition processes, Frat. Ed. Integrita Strutt, 2012, no. 22, pp. 69-84.

25. Moridi, A., Hassani-Gangaraj, S. M., Guagliano, M., Dao, M. Cold spraying coating: review of material systems and future perspectives. Surf. Eng. 2014, no. 30, pp. 369-395.

26. Marrocco, T, D., McCartney, G., Shipway, P. H., Sturgeon, A., Production of titanium deposits by cold-gas dynamic spray: numerical modeling and experimental characterization. Thermal Spray Technology, 2006, no. 15, pp. 263-272.

27. MacDonald, D., Fernandez, R., Delloro, F., Jodoin, B. Cold spraying of armstrong process titanium powder for additive manufacturing, Thermal Spray Technology, 2017, no. 26, pp. 598-609.

28. Steenkiste, T. H. V., Smith, J. R., Teets, R. E. Aluminum coatings via kinetic spray with relatively large powder particles. Surf. Coatings Technol., 2002, no. 154 , pp. $237-252$.

29. Gruicjic, M., Zhao, C. L., Tong, C. et al. Analysis of the impact velocity of powder particles in the cold-gas dynamic-spraying processes. Mater. Sci. Eng. A, 2004, no. 368, pp. 222-230.

30. Assadi, H., Gartner, F., Stoltenhoff, T., Kreye, $\mathrm{H}$. Bonding mechanism in cold gas spraying. Acta Mater., 2003, no. 6454, pp. 4379-4394.

31. Karthikeyan, J. The Advantages and disadvantages of the cold spray coating process, in the cold spray materials deposition process: fundamentals and applications. Wood head ; CRC Press Publ., 2007, pp. 62-71.

32. Meyer, M. An analysis of the particulate flow in cold spray nozzles. Mechanical sciences, 2015, vol. 2, no. 6, pp. 127-136.

33. Silvello, A. Mechanical properties of cold sprayed Titanium and Nickel based coatings. Surface Engineering, 2015, vol. 1, no. 15, pp. 153-154.

34. Lu, B., Wang, D. H., Xiao, L. et al. Microstructure Analysis of Laser Remelting for Thermal Barrier Coatings on the Surface of Titanium Alloy - International symposium on materials applications and engineering, France, EDP Sciences, 2016.

35. Li, W. Y., Li, C. J. Optimization of spray conditions in cold spraying based on the numerical analysis of particle velocity. Trans. Nonferrous Met. Soc. China, (special issues for the International Conference on Surface Engineering, 2004), 2004, vol. 2, no. 14, pp. 43-48

36. Cao, C. C., Li, W. Y. et al. Simulation study on effect of cold spray nozzle material on particle. Journal of netshape forming engineering, 2019, vol. 6, no. 11, pp. 149-153.

37. Li, C. J., Li, W. Y. Examination of the critical velocity for deposition of particles in cold spraying. Journal of Thermal Spray Technology, 2006, vol. 2, no. 15, pp. 212-222.

38. Qing, Y. C., Zou, Y. L. et al. Morphological, structural and mechanical characterization of cold sprayed hydroxyapatite coating. Surface and Coatings Technology, 2019, vol. 1, no. 357, pp. 910-923. 
39. Marple, B. R. et al. Effects of Gas Temperature, Gas Pressure and the Particle Characteristics on Cold Sprayed Pure Titanium Coating, in Thermal Spray 2009: Expanding Thermal Spray Performance to New Markets and Applications. ASM International, Las Vegas, NV, 2009, pp. 231-236.

40. Wong, W., Irissou, E. et al. Influence of helium and nitrogen gases on the properties of cold gas dynamic sprayed pure titanium coatings, in Thermal spray: Global Solutions for Future Application. ASM International, Singapore, 2010.

41. Kumar, S., Gyuyeol, B., Changhee, L. Deposition characteristics of copper particles on Foughened substrates through kinetic sprayin. Applied Surface Science, 2009, no. 255, pp. 3472-3479.

42. Yuan, X. et al. Interfacial diffusion behavior of cold sprayed aluminum alloy on the surface of magnesium alloy. Journal of welding, 2007, vol. 11, no. 28, pp. 9-11.

43. Zhang, H. et al. Microstructure of cold spray Ni coating. Chinese journal of nonferrous metals, 2008, vol. 8, no. 18, pp. 1421-1425.

44. Yu, S. Q, et al. Protection for cold sprayed coating on magnesium alloy. Surface technology, 2018, vol. 5, no. 47, pp. 43-56.

45. Li, X. F, et al. Application and prospect of cold spraying in welding engineering. Welding, 2008, no. 9 , pp. 13-16.

46. Liu, Y. X. Cold spray process for magnesium alloy and properties of coating. Shenyang university of technology, 2007.

47. Hu, J. W. et al. Cold spray copper coating on aluminum alloy substrate. Journal of Netshape Forming Engineering, 2019, vol. 6, no. 11, pp. 154-160.

48. Yu, S. Q. et al. Microstructure and corrosion behavior of cold sprayed aluminum alloy and aluminum matrix composite coating on magnesium alloy. Aerospace shanghai, 2018, vol. 4, no. 35, pp. 101-107.

49. Zhong, L., Wang, Z. Y., Zhang, H. D. Research progress of precipitation mechanism and apparatus of cold spray. Surface technology, 2015, vol. 4, no. 44, pp. 15-22.

50. Lei, J. Cold spraying powder for surface damage repair of thin walled titanium alloy parts and a method for repair. Patent China, no. CN109207988A, 2019.

51. Ogawa, K., Niki, T. Repairing of Degraded Hot Section Parts of Gas Turbines by Cold Spraying. Key Engineering Materials, 2010, vol. 417-418, pp. 545-548. DOI: 10.4028/www.scientific.net/KEM.417418.545 .

52. Champagne, V. K. The repair of magnesium rotorcraft components by cold spray. Journal of failure analysis and prevention, 2008, vol. 8, no. 2, pp. 164-175.

53. Li, W. Y. et al. Application of cold spraying technology in additive manufacturing and repair in the manufacturing field. Welding, 2016, vol. 4, pp. 1-8.

54. Pelletier, J. L. Development of Ti-6Al-4V coating onto Ti-6Al-4V substrate using Low Pressure Cold
Spray and Pulse Gas Dynamic Spray. University of Ottawa, Ottawa, Canada, 2013.

55. Dibakor, B., Bilal, A. et al. Evaluation of residual stresses induced by cold spraying of Ti-6Al-4V on Ti-6Al-4V substrates. Surface \& Coating Technology, 2019, no. 374, pp. 591-602.

56. Cao, C. C. et al. Influence of substrate hardness and thermal characteristics on micro-structure and mechanical properties of cold sprayed TC4 titanium alloy coating. Materials Reports, 2019, vol. 1, no. 33, pp. 277-282.

57. Yin, S. A systematic investigation on the acceleration behavior and deposition mechanism of cold sprayed particles. Dalian University of Technology, 2012.

58. Sunday, T. O. et al. A comparative review on cold gas dynamic spraying processes and technologies. EDP Sciences, 2019.

59. Liu, C. G. The analysis on the particles acceleration performance and deposition mechanism in the cold-gas dynamic spraying processes. University Of South China, 2015.

60. Li, T. F. et al. Development on Cold Spray Apparatus. Thermal Spray Technology, 2011, vol. 3, no. 2, pp. 15-34.

61. Zhao, M. Effects of particle and substrate property on impact and adhesion process in clod spray by numerical simulation. Chongqing university, 2015.

62. Wu, X. K., Zhou, X. L. et al. Numerical investigation on acceleration of gaseous mixture of nitrogen and helium on particles during cold spraying. Materials engineering, 2010, vol. 8, pp. 12-15.

63. Meng, X. M., Zhang, J. B. et al. Numerical simulation of the effects of the impact velocity on the particle deposition characteristics in cold gas dynamic spraying. Baosteel technology, 2011, vol. 5, pp. 17-22.

64. Han, L. et al. Critical deposition velocity calculations and properties investigations of TC4 cold spray coatings. Surface Technology, 2017, vol. 46, no. 8, pp. 96-101.

65. Yang, Y. et al. Research on Critical Velocity of Particle during Cold Spray Process. Thermal spraying technology, 2015, vol. 7, no. 4, pp. 1-16.

66. Marrocco, T. et al. Production of titanium deposits by cold-gas dynamic spray: Numerical modeling and experimental characterization. Journal of Thermal Spray Technology, 2006, vol. 2, no. 15, pp. 263-272.

67. Schmidt, T., Gartner, F. et al. Development of a generalized parameter window for cold spray deposition. Acta Materialia, 2006, vol. 3, no. 54, pp. 729-742.

68. Wong, W., Rezaeian, A. et al. Effects of Gas Temperature, Gas Pressure and the Particle Characteristics on Cold Sprayed Pure Titanium Coatings, in Thermal Spray 2009: Expanding Thermal Spray Perormance to New Markets and Applications. ASM International, Las Vegas, NV, 2009, pp. 231-236.

69. Wang, H. R., Li, W. Y., Ma, L., Wang, J., Wang, Q. Corrosion behavior of cold sprayed titanium protective coating on $1 \mathrm{Cr} 13$ substrate in seawater. Surf. Coatings Technol., 2007, no. 201, pp. 5203-5206. 
70. Zahiri, S. H., Antonio, C. I., Jahedi, M. Elimination of porosity in directly fabricated titanium via cold gas dynamic spraying. J. Mater. Process. Technol., 2009, no. 209, pp. 922-929.
71. Cizek, J., Kovarik, O., Siegl, J., Khor, K. A., Dlouhy, I. Infuence of plasma and cold spraying deposited $\mathrm{Ti}$ Layers on high-cycle fatigue properties of Ti6Al4V substrates. Surf. Coatings Technol., 2013, no. 217, pp. 23-33.

Поступила в редакцию 7.05.2020, рассмотрена на редколлегии 15.06.2020

\title{
РЕМОНТ ПОВЕРХОНЬ АВІАЦЙНИХ ДЕТАЛЕЙ 3 ТИТАНОВИХ СПЛАВІВ ХОЛОДНИМ ГАЗОДИНАМІЧНИМ НАПИЛЮВАННЯМ
}

\author{
Веньцзе ХУ, С. С. Маркович, Кунь Тань, О. В. Шорінов, Тинтін Цао
}

Перевагами титанових сплавів є висока питома міцність, хороша корозійна стійкість, висока жаростійкість, низька щільність, і використовуються в якості конструкційного матеріалу для виготовлення деталей аерокосмічної техніки, таких як лопатки компресора, патронний приймач, гондола двигуна, теплова перегородка і так далі. В даний час в аерокосмічній промисловості використовується близько трьох чвертей титану і титанових сплавів в світі. У процентному співвідношенні кількість деталей з титанових сплавів в літаках А 350 становить 14\%, F18 - 15\%, В787 - 15\%, Су-57 - 18\%, J-20 - 20\%, винищувачі FC-31 - 25\%, F35 - $27 \%$, F22 - до 41\% і т. д., а даний метал має репутацію «літаючого металу». Однак його низька зносостійкість обмежує широке застосування титанових сплавів. Ще одним недоліком деталей з титанових сплавів є їх висока собівартість виробництва. Тому вивчення і розвиток технологій захисту і поліпшення авіаційних титанових сплавів має велике значення. В даний час використовуються металургійний спосіб підвищення зносостійкості за рахунок застосування легуючих добавок, а також технологій нанесення покриттів. Існує багато технологій нанесення покриттів, наприклад, високошвидкісне газо-полуменеве напилювання (HVOF), наплавка, детонаційне, плазмове напилювання та інші. У даній роботі розглянута перспективна технологія холодного газодинамічного напилювання для ремонту і відновлювання деталей з титанових сплавів. Перевагами технології в порівнянні з іншими методами нанесення покриттів $є$ низька температура процесу, відсутність окислення і структурно-фазових перетворень в матеріалах покриття і підкладки, відносно низька собівартість отримання покриттів. Покриття мають високу міцність зчеплення 3 підкладкою, мікротвердість і низьку пористість. У даній статті розглянуто області застосування авіаційних титанових сплавів, наведено приклади деталей з даних сплавів, проаналізовано дефекти і причини їх виникнення. Виконано аналіз останніх робіт в області поверхневого ремонту деталей з титанових сплавів за допомогою технології холодного напилювання, проаналізовано технологічні параметри процесу формування покриттів, в тому числі розмір часток напилюваного порошку, морфологія, швидкість і температура частинок в процесі напилювання, вплив попереднього нагріву підкладки на адгезію міцність системи покриття/підкладка та інше.

Ключові слова: титанові сплави; відновлення поверхні; холодне напилювання; захисне покриття; технологічні параметри.

\section{РЕМОНТ ПОВЕРХНОСТЕЙ АВИАЦИОННЫХ ДЕТАЛЕЙ ИЗ ТИТАНОВЫХ СПЛАВОВ ХОЛОДНЫМ ГАЗОДИНАМИЧЕСКИМ НАПЫЛЕНИЕМ}

\author{
Веньцзе ХУ, С. Е. Маркович, Кунь Тань, А. В. Шоринов, Тинтин Цао
}

Титановые сплавы обладают преимуществами высокой удельной прочности, хорошей коррозионной стойкости, высокой жаростойкости, низкой плотности, и используются в качестве конструкционного материала для изготовления деталей аэрокосмической техники, таких как лопатки компрессора, патронный приемник, гондола двигателя, тепловая перегородка и так далее. В настоящее время в аэрокосмической промышленности используется около трех четвертей титана и титановых сплавов в мире. В процентном соотношении количество деталей из титановых сплавов в самолетах А350 составляет $14 \%$, F18 - $15 \%$, В787 $15 \%$, Су-57 - 18 \%, J-20 - 20 \%, истребители FC-31 - 25 \%, F35 - 27 \%, F22 - до 41 \% и т. д., а данный металл имеет репутацию «летающего металла». Однако его низкая износостойкость ограничивает широкое применения титановых сплавов. Еще одним недостатком деталей из титановых сплавов является их высокая себестоимость производства. Поэтому изучение и развитие технологий защиты и улучшений авиационных титановых сплавов имеет большое значение. В настоящее время используются металлургический способ повышения износостойкости за счет применения легирующих добавок, а также технологии нанесения покрытий. Существует множество технологий нанесения покрытий, например, высокоскоростное газопламенное напыление (HVOF), наплавка, детонационное, плазменное напыление и другие. В данной работе рас- 
смотрена перспективная технология холодного газодинамического напыления для ремонта и восстановления деталей из титановых сплавов. Преимуществами технологии в сравнении с другими методами нанесения покрытий является низкая температура процесса, отсутствие окисления и структурно-фазовых превращений в материалах покрытия и подложки, относительно низкая себестоимость получения покрытий. Покрытия обладают высокой прочностью сцепления с подложкой, микротвердостью и низкой пористостью. В данной статье рассмотрены области применения авиационных титановых сплавов, приведены примеры деталей из данных сплавов, проанализированы дефекты и причины их возникновения. Выполнен анализ последних работ в области поверхностного ремонта деталей из титановых сплавов с помощью технологии холодного напыления, проанализированы технологические параметры процесса формирования покрытий, в том числе размер частиц напыляемого порошка, морфология, скорость и температура частиц в процессе напыления, влияние предварительного нагрева подложки на адгезию прочность системы покрытие/подложка и т.д.

Ключевые слова: Титановые сплавы; восстановление поверхности; холодное напыление; защитные покрытие; технологические параметры.

Веньцзе Ху - аспирант, факультет авиационных двигателей, Национальный аэрокосмический университет им. Н. Е. Жуковского «Харьковский авиационный институт», Харьков, Украина; Школа аэронавтики и космонавтики, Наньчанский технологический институт, Китай.

Маркович Сергей Евгеньевич - канд. техн. наук, доцент, помощник ректора по инновационной деятельности, Национальный аэрокосмический университет им. Н. Е. Жуковского «Харьковский авиационный институт», Харьков, Украина.

Кунь Тань - аспирант, факультет авиационных двигателей, Национальный аэрокосмический университет им. Н. Е. Жуковского «Харьковский авиационный институт», Харьков, Украина; Китайский Стипендиальный Совет, Китай.

Шоринов Александр Владимирович - канд. техн. наук, ассистент каф. технологии производства авиационных двигателей, Национальный аэрокосмический университет им. Н. Е. Жуковского «Харьковский авиационный институт», Харьков, Украина.

Тинтин Цао - магистр школы авиационного машиностроения, Университет Наньчан Хангонг, Наньчан, Китай; Школа аэронавтики и космонавтики, Наньчанский технологический институт, Китай.

Wenjie Hu - PhD student of Faculty of aircraft engines, National Aerospace University "Kharkiv Aviation Institute", Kharkiv, Ukraine; School of Aeronautics and Astronautics, Nanchang Institute of Technology, China, e-mail: 837406613@qq.com, ORCID Author ID: 0000-0001-9540-1912.

Sergii Markovych - PhD, Associate professor of Dept. of aircraft engine manufacturing technologies, Deputy rector for innovation, National Aerospace University "Kharkiv Aviation Institute", Kharkiv, Ukraine, e-mail: s.markovych@khai.edu, https://scholar.google.com.hk/citations?hl=zh-CN\&user=1qCHkosAAAAJ

Kun Tan - PhD student of Faculty of aircraft engines, National Aerospace University "Kharkiv Aviation Institute", Kharkiv, Ukraine; China Scholarship Council, e-mail: 743733679@qq.com, ORCID Author ID: 0000-0003-4889-785X.

Oleksandr Shorinov - PhD, Assistant lecturer of Dept. of aircraft engine manufacturing technologies, National Aerospace University "Kharkiv Aviation Institute", Kharkiv, Ukraine, e-mail: shorinov1@gmail.com, ORCID Author ID: 0000-0002-5057-6679, https://scholar.google.com.hk/citations?hl=zh-CN\&user=xLOM1ccAAAAJ

Tingting Cao - Master of School of Aircraft Engineering, Nanchang Hangkong University, Nanchang, China; School of Aeronautics and Astronautics, Nanchang Institute of Technology, China, e-mail: 903301019@qq.com. 